\title{
Shakespeare and Chess Again: A Proposal for an Alternative Reading of pawn(s) in King Lear, King John and The Winter's Tale
}

\author{
José Luis Oncins Martínez \\ Universidad de Extremadura
}

\begin{abstract}
For the last three centuries, Shakespeare's plays have been continuously glossed, commented on and annotated. However, there still remain quite a few obscure passages and complex words which continue to puzzle and cause debate as to their precise meanings. One such word is pawn, glossed as a pun in some editions of King Lear, and passed over in silence in other plays where it appears in similar contexts.

This essay proposes an alternative reading of the word in King Lear, King John and The Winter's Tale. The hypothesis put forward is that Shakespeare was indeed hinting at the various senses of this word and exploiting its punning potential in these three plays. This suggestion is supported by a series of examples of similar rhetorical exploitation of this polysemic word as found in several contemporary authors. These examples will demonstrate that the various senses of the word were indeed very much alive in Elizabethan England - and quite probably in Shakespeare's mind.
\end{abstract}

KEYWORDS: Shakespeare's style, chess, metaphor, wordplay, pun.

You must get into the habit of looking intensely at words, and assuring yourself of their meaning [...] Never let a word escape you that looks suspicious. It is severe work; but you will find it, even at first, interesting, and at last, endlessly amusing.

John Ruskin Sesame and Lillies (qtd Foster 1908:xi)

(G) ederi 21 (2011): 29-47

https://doi.org/10.34136/sederi.2011.2 


\section{Introduction}

Shakespeare's plays and poems have been the object of scholarly study for more than three centuries now. During this time, they have not only been continuously edited, glossed and annotated, but also constantly commented on, analyzed and scrutinized. As far as their language and style are concerned, this critical activity became especially prolific in the twentieth century, boosted no doubt by the birth and development of modern linguistics. Indeed, ever since William Empson published his seminal work Seven Types of Ambiguity (1930) and later The Structure of Complex Words (1951) thus paving the way for the New Criticism - much has been said and written about Shakespeare's language. Since then, many approaches and theories have been proposed and used for analyzing his texts: from the traditional philological methods, like those by Clive S. Lewis (1960) or Molly Mahood (1957), to more theoretically-oriented approaches such as Patricia Parker's (1996) feminist-historical reading of Shakespeare's wordplay or Mary T. Crane's (2001) cognitive analysis of the same phenomenon in some of his plays.

Although one is tempted to think that three centuries of critical and editorial work should be enough to have settled any controversies over Shakespeare's meaning and exhausted all possible interpretations, there still remain quite a few obscure passages and complex words which continue to puzzle and give rise to debate as to their precise meanings. Only that may explain why, hundreds of articles, critical editions, glossaries and dictionaries continue to be published every year, proposing alternative readings that keep on adding to an ever-growing corpus of interpretations. This wealth of criticism seems to confirm John Dryden's famous dictum that, at least in the case of Shakespeare, "the last [word] is not yet sufficiently explicated," a view shared today by many scholars, like Norman Blake (1999), who believes that there is still much to discover about Shakespeare's meaning. The main reason why this is so - Blake argues - is that editors have for too long focused on the play's theatrical and cultural background, leaving language and its meaning relatively neglected (Blake 2002:28).

On the other hand, since new theories and analytical tools for approaching the study of language continue to appear, one still hopes that they can contribute to the debate on "Shakespeare's meaning" by providing new angles from where to approach the text 
and explore it. One such new theory that has recently come to enrich the debate is Cognitive Linguistics. The interest of cognitivism in Shakespeare touches on various aspects of his language, such as metaphor, metonymy or polysemy, and is reflected in the works of cognitive stylisticians like Freeman (2002, 2004 [1995]), or cognitive literary critics like Crane (2001), to whom this essay owes much of its thrust. In her Shakespeare's Brain - a cognitive approach to the Shakespearean lexicon - Crane explores "what seems to be a special focus on polysemic words of various kinds, especially those that were taking on new meanings in this period in concert with significant institutional and cultural changes" (Crane 2001:25). She focuses on villain and clown in As You Like It, house and home in The Comedy of Errors, suit in Twelfth Night, pregnant in Measure for Measure, act in Hamlet and pinch in The Tempest. Although the readings that Crane produces may seem similar to the ones proposed by some of the authors mentioned above, she draws on a different theory of meaning and, consequently, her analyses reveal different features of Shakespeare's art and style. ${ }^{1}$

Like Crane's book, this essay focuses on the analysis of a word that corresponds to two homonyms whose meanings were being extended in Early Modern English to become polysemous: the noun pawn. Although this noun has five different entries in the Oxford English Dictionary (henceforth OED), attention will be paid only to pawn $n .^{1}$ and pawn $n .{ }^{2}$, as they are the ones which are relevant to my purpose here. According to the OED, pawn $\left(n .^{1}\right)$ is, in its first sense, "One of the pieces of smallest value in the game of chess." It comes from Latin pedo, pedōn-em (in med. Latin a foot-soldier) and enters the English language in the fourteenth century through French (the chess sense was in Old French in $13^{\text {th }}$ century). Later on $\left(14^{\text {th }} \mathrm{c}\right.$.), it develops a figurative sense to refer to a person. On the other hand, pawn $\left(n .^{2}\right)$ is borrowed into Middle English from Old French pan ("pledge, security, surety"), the source of which could be either Romanic (L. panus) or Teutonic (WGer. pand) (see OED). In Early Modern English its primary sense is "A thing (or person) given,

\footnotetext{
${ }^{1}$ Cognitive theory - Crane claims - offers "more than a materialist or historicist supplement to formalism, providing in addition a way of tracing in the text the interactions between culture, language, and cognition" (2001:25). She then goes on to spell out in detail those aspects in which her cognitive approach to the Shakespearean lexicon differs from previous studies on words, such as Empson's or Parker's, among others (2001:29-33).
} 


\section{J. L. Oncins Martínez}

deposited, or left in another's keeping, as security for a debt or for the performance of some action." Like pawn $\left(n .^{1}\right)$, its meaning was also extended later to apply specifically to human beings: "Id. a person held as a pledge or security for debt, and used as a slave."

Surprisingly, in spite not only of this word's stylistic relevance in some Shakespearian passages but also of its semantic potential confirmed by the fact that it was used punningly by other wellknown Elizabethan authors - its exact meaning seems to have passed almost unnoticed by most of the editors of the plays in which it appears; only King Lear's pawn (I.i.155) seems finally to be receiving its due attention, as I will show, and in this case only recently. The same lack of attention is to be found in lexicographers, whose definitions and glosses refer almost exclusively to pawn $\left(n .^{2}\right)$ to the detriment of pawn $\left(n .{ }^{1}\right)$, which does not even appear in the major glossaries and dictionaries. $^{2}$

\section{Aims of this essay}

The hypothesis put forward in this essay is that Shakespeare was indeed hinting at the various senses of this word and exploiting its punning potential in King Lear, but also in King John and The Winter's Tale, two plays where editorial silence on pawn remains almost absolute to date. ${ }^{3}$ This suggestion is supported by a series of examples of similar rhetorical exploitation of this polysemic word as found in several contemporary authors. These examples will demonstrate that the various senses of the word were indeed very much alive in Elizabethan England - and, I would dare to say, in Shakespeare's own mind -, and that this word was part of the stock repertoire of puns at the time. Besides, the possibility of gathering evidence from other authors in order to cast some light on Shakespeare's meaning allows me to situate his work in the wider

\footnotetext{
${ }^{2}$ See, for example, Foster (1908), Crystal (2004) or Schmidt (1971). Onions, who does not gloss the chess sense of pawn, at least concedes that in King Lear, whose pawn he explains as "stake", "there may be a reference to the pawn in chess" (Onions 1978:159).

${ }^{3}$ Of the dozens of editions of the three plays consulted for this survey, including Furness's Variorums (see references), only Honigmann (1954) makes a very timid allusion to the game of chess in King John; but he does not seem to identify any pun on the two senses of the word, which he glosses simply as "articles in pawn."
} 
cultural and social context in which it was produced (Crane 2001:13; 25). By doing so, I am also trying to avoid not only the risks of taking for granted, and reproducing, the glosses and commentaries accumulated throughout the years but some of the disadvantages of drawing on Shakespeare's own language - and only on his - to explain Shakespeare's language.

Another reason that leads me to believe that there is more to Shakespeare's pawn than editors and lexicographers noticed up to now is the way in which the term has been translated into other languages, and more specifically into Spanish. In other words, my suspicion that the exact meaning of pawn "is not yet sufficiently explicated" - to borrow Dryden's words again - is reinforced by the fact that the word has given rise to disparate interpretations in some of the most widely read Spanish translations of King Lear, for example. Thus, whereas Valverde (1967) translates pawn as "prenda," Conejero et al. (1995) and Pujante (1992) opt for "peón" and "apuesta," respectively. ${ }^{4}$ In this sense, I would like to think that close readings like the one proposed in this essay can be of some use to those who translate Shakespeare plays and poems, a difficult enterprise - always challenging and very often unfairly underrated that requires the scholar's erudition, as well as the craftsmanship of the artist. $^{5}$

In the following sections I will firstly present and briefly comment on a few instances of the word pawn involving some sort of wordplay from texts by other very well-known Elizabethan authors, namely, John Lyly, Francis Bacon and Thomas Dekker. Then, the

\footnotetext{
${ }^{4}$ Astrana (1928) - the author of the most popular and widely-circulated translation of Shakespeare's works in Spanish - also gives "peón". Here are the four translations of Kent's sentence where pawn appears: “iMi vida! Nunca la he considerado sino como peón, para jugármela contra tus enemigos; ni tengo miedo a perderla, siendo el motivo de tu bien" (Astrana); "Mi vida nunca la he considerado más que como una prenda que poner en juego contra tus enemigos, sin temer jamás perderla cuando era cosa de tu seguridad" (Valverde); "Mi vida nunca fue sino un peón jugado en contra de tus enemigos; nunca temí perderla si era el motivo tu seguridad" (Conejero et al.); and "Mi vida siempre tuve por apuesta en las partidas contra tus enemigos y no temo perderla por salvarte" (Pujante).

${ }^{5}$ It might be argued that every new reading (especially when it involves some kind of pun) makes matters even more complicated for translators. However, good translators manage to push the resources of a language very far, and in view of the highly imaginative solutions that the aforementioned translators have come up with for other extremely difficult passages, I am convinced that they are not easily put off.
} 


\section{J. L. Oncins Martínez}

three Shakespearian passages that the essay is concerned with will be discussed, starting with the instance in King Lear, followed by those in King John and The Winter's Tale. For the "pawns" in these last two plays, I will be proposing some alternative interpretations which, far from invalidating previous ones, may serve, I hope, to complement and enrich them. The essay concludes that, as so often with Shakespeare, there may be more to an apparently unambiguous word than the notes and glosses of editors and lexicographers would lead us to believe; and so that, in the case of Shakespeare's texts, Ruskin's advice is worth keeping in mind today.

\section{Pawn in Early Modern English literature}

The earliest documented usage of pawn $\left(n .^{1}\right)$ - the homonym that denotes the chess piece - dates according to the $O E D$ from towards the beginning of the Late Middle English period (1369). ${ }^{6}$ Out of this primary sense a figurative one developed in Early Modern English which came to extend the meaning of the noun to refer to human beings as well: "b. fig. usually of a person" (OED). This new sense is first documented in 1589, with a quotation from Pappe with an Hatchet, a famous pamphlet attributed to John Lyly as his contribution to the Martin Marprelate controversy on the side of the Anglican bishops. The nature of the controversy is relevant for reasons that the text of the pamphlet will make clear:

If a Martin can play at chestes as well, as his nephewe the ape, he shall knowe what it is for a scaddle pawne to crosse a Bishop in his owne walke. Such dydoppers must be taken vp, els theile not stick to check the king. (Lyly 1589 [1902. vol III]:394-395)

It may not be out of place to remember that the word Bishop was also used in Early Middle English to refer to the chess piece, hitherto known as archer, prince (OED 9. Obs. rare) or, still earlier, alfin. Incidentally, although this is the $O E D^{\prime}$ s first quotation for this figurative use of pawn, John Lyly had already used the word with the same sense a few years earlier in Euphues (1578). Moreover, and this is perhaps more interesting, in this work the word also appears in a

\footnotetext{
${ }^{6}$ For the periods in the history of English, I am using the same conventions as Traugott and Dasher (2002:xiv).
} 
context in which the game of love and the game of chess are made to coalesce into a metaphor built upon several key words:

Ah, Liuia, Liuia, thy courtly grace $[. .$.$] haue giuen me such a checke$ [that] sure I am at the next view of thy vertues I shall take thee mate: And taking it not of a pawn but of a prince [the] loss is to be accompted the lesse. And though they be comonly in a great choler that receiue the mate, yet would I willingly take euery minute [the] mates to enioy Liuia for my louing mate. (Lyly 1578 [1902 vol I]:212-213; my emphasis)

Whether or not Shakespeare ever read this passage is not necessarily relevant. What is important is the currency of the chess metaphor and its vocabulary for the possibilities that they afforded authors prone to punning and wordplay. Be that as it may, it seems more than likely that Shakespeare knew of Lyly's work. Critics have drawn our attention to Falstaff's parody of his euphuistic style in Henry IV I (Bevington 1998:199; 266), to a passage from Euphues as the source for the simile of the honey-bees in Henry $V$ (see, e.g., Humphreys 1968, or Bulman 1985:37) or to the speech of Capulet's old servant in Romeo and Juliet (I.ii.34-61) in which Shakespeare ridicules the outworn conventions of Lyly's famous work (see, e.g. Tilley 1926).

The word pawn also occurs in a more serious play on words found in Francis Bacon's "Apologie [in Certaine Imputations Concerning the Late Earle of Essex]" (1604) to Queen Elizabeth. Towards the end of the text, Bacon expresses his feelings to the Queen after having fallen from her favour, likening himself to an insignificant pawn before the king (note the pun on a pawn-upon in the last sentence):

I dealt with her plainly; and said, Madam, I see you withdraw your favour from me, and now I have lost many friends for your sake, I shall lose you too: you have put me like one of those that the Frenchmen call enfans perdus, that serve on foot before horsemen, so have you put me into matters of envy without place, or without strength; and I know at chess a pawn before the king is ever much played upon. (Bacon 1604 [1857]:155)

The metaphor of the game of chess, a symbolic reflection of social order, is now turned upside down by Bacon to represent the real facts of life: his dramatic downfall in the social hierarchy from his role as a "knight" to that of a horseless, insignificant "pawn." 


\section{J. L. Oncins Martínez}

Again, there is no sure way to know if Shakespeare was acquainted with the text of the "Apologie," let alone whether he may have found in it any inspiration for his own material. What we do know is that the letter was widely circulated, with a second impression issued in 1605 (Coquillette 1992:185). After all, this was Bacon's aim in writing it: to defend himself publicly to "the vulgar sort," against charges of being "false or unthankful" to the Earl of Essex.

The polysemic nature of pawn $\left(n{ }^{1}\right)$ already makes it an attractive and dynamic term for a Renaissance audience. If we add to this the literal and figurative senses of its homonym pawn $\left(n .^{2}\right)$, noted above, it is not difficult to understand why the word did not go unnoticed by Renaissance authors so sensitive to puns, quibbles and all sorts of wordplay. One of them, Thomas Dekker, takes advantage of the various senses that converge in this word in two of his works, "News from Hell" and The Whore of Babylon, both written around the same year (1606-1607). In both, he quibbles doubly on the same words, pawn and knight, giving rise to a double antanaclasis. Here is the text of "News from Hell:"

[...] because when I prepared to fight a battle on the chess-board, a knight was always better than a pawn: but the usurer my uncle made it plain, that a good pawn now was better then a knight.

The pun here hinges on the two senses of knight (chess piece and "man of noble birth and high social rank") and pawn (chess piece and "pledge or security for debt"). The same pun is repeated in the form of a dialogue between Titania and Plain Dealing in The Whore of Babylon:

PLAIN DEALING. [...] It is the strangest chessboard in the world.

TITANIA. Why?

PLAIN D. Because in some games at chess knights are better than pawns, but here a good pawn is better than a knight. (The Whore of Babylon II.i.94-97)

In both cases what is highlighted with this pun is the great distance that exists between the old order, symbolized in the game of chess, where knights are worthier than pawns, and the harsh reality of the material world, where a good pawn, i.e., money, is more highly valued than social position. Through this pun, Dekker 
manages to fuse economic and social values, hinting at their evolution as seen through the evolution of the form pawn. ${ }^{7}$

\section{Pawns in Shakespeare}

\subsection{King Lear's pawn}

The repeated occurrence of these various quibbles on pawn suggests that Shakespeare must have been familiar with, and aware of, the stylistic potential of the word. Besides, even though allusions to the game may be rare in Shakespeare (Loughrey and Taylor 1982:13), that does not necessarily mean that he was not familiar with the game, as direct references to it appear in his plays - think of Ferdinand and Miranda engaged in a chess game in The Tempest (see, e.g., Poole 2004) ${ }^{8}$-, and some nouns and verbs like check, mate and even pawn seem to have been used by Shakespeare in a chess sense. ${ }^{9}$ Besides, as Yachnin (1982) convincingly argues, one does not have to know or love the game to draw on its metaphors if need arises. James I himself had publicly declared his dislike for the game, but he had no qualms in invoking its authority in a speech before Parliament:

[Kings] have power to exalt low things, and abase high things, and make of their subjects like men at the Chesse; a pawne to take

\footnotetext{
${ }^{7}$ Still one further example of the punning possibilities of this word is to be found in Jonson's The Magnetic Lady, not mentioned above because it involves a sense of the noun not used by Shakespeare: pawn, n.3 = a peacock $(O E D)$. See the note in Happé's edition (2000:67).

${ }^{8}$ In his edition of Middleton's A Game at Chess, Howard-Hill (1993) also includes The Tempest among the contemporary plays with references to chess. He talks about "the power of chess as a dramatic metaphor" fostered by the popularity of the game in Shakespeare's England and before: "Chess had a long history in European allegory, in which Caxton's The Game and Play of Chess (1475) is the Earliest English representative, and chess play had already been shown on stage (e.g. Shakespeare's The Tempest, Fletcher's The Spanish Curate) when Middleton began to consider his play" (1997:28). Harper thinks likewise (1966). For a different view of the popularity of chess in Shakespeare's England, see Pujante (1985:15; and the introduction to his translation of Middleton's famous play into Spanish [1983]:33-34).

${ }^{9}$ See, for example, the editorial comments on queen and check in King John II.i.123 and V.i.73 (Braunmuller 1989), mate in 2 Henry VI III.i.264 (Knowles 1999) and The Taming of the Shrew I.i.58 (Oliver 1982), or pawn in King Lear I.i.155 (Wells 2000).
} 
a Bishop or a Knight, and to cry up, or downe any of their subjects. ${ }^{10}$

There seems to be little doubt today that Shakespeare exploits the homonymic and polysemic nature of the noun pawn, at least in King Lear, the only play in which editors seem now to agree that the chess sense is relevant to the context in which the word appears. The word occurs in the course of the heated argument between Lear and Kent in the opening scene, where the latter tries to convince Lear that his "youngest daughter [Cordelia] loves thee [Lear] not least." The king orders Kent to stop but he insists. Lear warns him: "Kent, on thy life, no more." Kent, picking up Lear's life, replies:

My life I never held but as a pawn,

To wage against thine enemies, never feared to lose it,

Thy safety being motive. (King Lear I.i.155)

The quibble on pawn has indeed been pointed out by one of the play's recent editors, Stanley Wells, who remarks: "pawn ... wage. Stake to wager (with a glance at the sense of pawn as the piece of lowest value in the game of chess)" (2000:108). Thus, in Kent's words, the metaphor presents the double perspective made possible by at least two of the senses of pawn, supported and reinforced by wage (meaning both "to pledge" and "to make war"). On the one hand, Kent considers his life a pledge to be waged or staked in a war against the King's enemies. On the other, in a soldier-like manner, he boasts that he never considered his life and himself but as a pawn or humble servant at his king's service, waging war against those same enemies.

Even though nowadays Kent's pawn is probably one of the few widely-acknowledged references to chess in Shakespeare, its editorial history demonstrates that Blake's complaint about the lack of interest in studying Shakespeare's language is not without foundation. The first editor to suggest that pawn here might refer to the chess piece was, according to Furness, Capell: "154 pawn] STEEVENS: That is, a pledge. CAPELL, followed by HEANLEY, strangely thinks that this refers to the pawn in a game of chess" (Furness 1880:24). In the twentieth century, as new critical editions of the play were published, pawn began to attract the attention of editors as a polysemic noun and, what is more important, Capell's hypothesis of

${ }^{10}$ Speech to Parliament, 21 March 1609 (qtd Yachnin 1982:317). 
the pawn = chess piece seemed to gain ground. Thus, W. J. Craig, the editor of the Arden Shakespeare's King Lear (1901), differs slightly from previous editors in glossing pawn as "a stake which is hazarded in a wager," pointing out that this is "the only instance in Shakespeare of its use in this sense [...] he usually employs the word in the sense of pledge, something given as a security" (1901:15). Moreover, Craig, like Furness, also mentions Capell's reading, but unlike his predecessor he does not find it so far fetched: "Capell thinks there is an allusion to the game of chess" (ibid.). Later on, Kenneth Muir, Craig's successor as the editor of King Lear for the Arden Shakespeare (1952), contributes to the debate by providing some further evidence of the semantic complexity of the word. In his gloss to Kent's speech, he also interprets pawn to mean "a stake hazarded in a wager," and agrees with Capell that the noun is indeed usually employed by Shakespeare in the sense of pledge, but disagrees with him in his view that this is the only instance of its use in this sense in Shakespeare by pointing out two other quotations where pawn (v.) is used in the sense of stake: Cymbeline, I.iv.19 and The Two Gentlemen of Verona, I.ii.83 (Muir 1952:13). In addition, Muir insists on Capell's hypothesis, which he seems to share: "Capell thought there was an allusion to the game of chess, and there may have been a concealed pun" (ibid.).

Some might argue that Muir, who had just published his wellknown essay on serious puns in Macbeth (Muir 1950), must have found this an irresistible "uncomic pun." Be that as it may, the fact remains that today the editors who, following Muir, adhere to Capell's reading are more numerous than those who do not mention it. ${ }^{11}$ For example, J. L. Halio, the editor of The New Cambridge Shakespeare's King Lear, glosses pawn as stake ("as in a wager"), and also agrees that the word "may involve a metaphor from chess" (1992:104). Mowatt and Werstine (1993:16) also find a play on words and explain pawn as "(1) something to be set at risk; (2) Chess piece of least value." Andrews (1993:14) introduces an interesting semantic nuance by distinguishing the figurative (b) and the literal (c) senses of the chess piece: "Pawn, (a) pledge (as in a gauntlet cast down to engage a man in chivalric combat), (b) lowly servant, and (c) humble

${ }^{11}$ R.A. Foakes, editor of King Lear for the Arden 3 rd series, does not seem to share Craig's and Muir's view, however. He glosses pawn only as "Pledge, to fight" (1997:168). 
chess piece." More recently, the quibble on the various senses of pawn has also been pointed out by Wells (2000:108), whose gloss has already been given above: "pawn ... wage. Stake to wager (with a glance at the sense of pawn as the piece of lowest value in the game of chess)."

\subsection{Chess and pawns in King John}

Far less popular than King Lear, King John has received comparatively less attention and, in consequence, the figurative use of pawn in this play has gone practically unnoticed. The noun appears in plural form in V.ii, in the course of the speech delivered by Philip the Bastard before Louis the Dauphin on behalf of the King of England, in which he makes clear the consequences of failing to surrender. If they do not put down their arms, Philip warns them, the English King will fight them with the same hand that

[...] had the strength, even at your door,

To cudgel you and make you take the hatch,

To dive like buckets in concealed wells,

To crouch in litter of your stable planks,

To lie like pawns lock'd up in chests and trunks. (King John V.ii.141)

As can be seen, the context in which pawns appears in King John is very similar to that of King Lear. In both plays, the noun is used figuratively to refer to soldiers who serve their King. But whereas in King Lear Kent's likening of himself to a pawn brings into relief his soldierly qualities of humbleness and obedience, in King John what is brought into prominence is the poor quality of the French army, whose soldiers are characterized as pieces of the smallest value.

Once again, the play on pawn gives rise to a two-fold image: on the one hand, for the English, the French soldiers are nothing but objects left as security for a loan, locked up, and hence useless (Braunmuller 1989:252); and on the other hand, helped by the homophony chests = chess (see OED chess, ni 1.b), they appear as simple pawns, foot soldiers of the lowest rank, locked up in a game of chess = war, another recurring metaphor. 
All the major editions I have consulted gloss pawn as "articles in pawn" or "pawned goods."12 Loughrey and Taylor (1982:13), in their article on the chess game in The Tempest, venture to suggest very tentatively that this could be one of only three references to chess in Shakespeare, together with Kent's pawn in King Lear and another line from King John (1.1.155) where the words queen and check feature; but none of these, they say, is definitely an allusion to chess. However, it seems to me that Philip's speech certainly contains a chess allusion, which can be plausibly explained not only on the grounds of the examples from Shakespeare's contemporaries given earlier, but also with reference to his own words elsewhere in this play. Indeed, a few lines earlier, Philip the Bastard, angry that such an inexperienced soldier as the Dauphin dares to challenge the English, encourages his king to declare war on the French by using another chess word, check:

Shall a beardless boy

A cocker'd silver wanton, brave our fields

Flesh his spirits in a warlike soil [...]

And find no check? (King John V.i.69-73)

It must be remembered that this word had already appeared at the beginning of the play in another chess metaphor/pun, the second most widely acknowledged reference to chess in Shakespeare after King Lear's: ${ }^{13}$

Queen Eleanor [to Constance]:

Out, insolent! Thy bastard shall be king

That thou mayst be a queen and check the world. (King John II.i.123)

I do not think it is accidental either that only six lines before Philip calls the French soldiers "pawns" he has already insulted

\footnotetext{
${ }^{12}$ See, e.g., Wilson (1936), Matchet (1966), Smallwood (1974), Bevington (1980), Evans (1997) or Beaurline (1990). As was pointed out earlier (see note 3, above), Honigmann (1954) is the only editor who suggests a play on words in this passage, but in chess. In his gloss to "chests and trunks" he says: "chests (= chess) and trunks (a kind of billiards) were games, chests involving pawns, so he hints that the English played with the French" (130). In her Dictionary of Shakespeare's Semantic Wordplay, G. West (1998) also points out this pun: "The Bastard claims that in France King John has already put the French to rout and shown he has "the strength [...] to make you take the hatch [...] to lie like PAWNS lock'd up in CHESTS and trunks." Chess is spelled chests etc in OED's 16th and 17th century examples" (West 1998:28).

${ }^{13}$ See references to glosses and notes on this pun in note 9 above.
} 
them and questioned their "stature" as soldiers by referring to them as "boyish troops [...] this dwarfish war, these pigmy arms" (V.ii.133-135).

\subsection{Pawn in The Winter's Tale}

The word pawn appears three times in The Winter's Tale: once in Act II (iii.165), and twice in Act IV (iv.801 and 816). In IV.iv., the words occur in close proximity, first pronounced by one character and then picked up and repeated by another. Although editors of the play take the word to be used in the same sense in the play "pledge" (pawn n. $\left.{ }^{2}\right)-{ }^{14}$ I suspect that its second occurrence in Act IV may also hint at one of the figurative senses of pawn $n^{1}$. This is the context in which the words occur. In scene iv, the Clown and his father, the Old Shepherd, bump into Autolycus the rogue on their way to the king's palace. Autolycus pretends to be a courtier, "one that will either push on or pluck back thy business there" (IV.i.731732). The gullible rustics are fooled ("He seems to be of great authority," says the Clown [794]), and offer him some gold to have their business undertaken for them at court: "Old Shepherd: Here is that gold I have. I'll make it as much more, and leave this young man in pawn till I bring it you" (80o-803). Here, the Old Shepherd uses "pawn" in its sense of "pledge", i.e., he will leave his son as security for more money. Then the Clown, fearing that they may not be able to reach the palace, offers to double the amount: "Clown: I will give you as much as this old man does when the business is performed, and remain, as he says, your pawn till it be brought you" (814-815).

It seems to me that this second occurrence of pawn also involves the sense of pawn = "chess piece" when applied figuratively to persons. The context of the conversation in which the words are used would contribute to activate this sense. The Clown's position on the chessboard of courtly life is that of a pawn, while Autolycus has been taken for a knight. In calling himself a "pawn" the Clown is loading the term with the aforementioned connotations of a lower rank, humbleness and even servitude, thus offering himself to Autolycus also as his servant. In other words, by confirming his father's words

\footnotetext{
${ }^{14}$ See editions consulted in References.
} 
("as the old man says") the Clown assumes the sense of pawn $n .^{2}$, "thing (or person) left as security for a debt," while simultaneously implying the figurative sense of pawn $n .{ }^{1}$, whose connotations turn him into a servant. Moreover, in Shakespeare the collocation "remain + servant" is not infrequent; examples can be found in Antony and Cleopatra (V.ii) and Cymbeline (I.i.), for instance.

Immediately after the exchange, Autolycus bids them to "Walk before" - an order that the Old Shepherd repeats ("Let's before, as he bids us"). Whether or not these directions have to do with the movements of the pawn on the chessboard is difficult to say. However, it may not be irrelevant to point out that in one of the Royal Shakespeare Company productions of The Winter's Tale (directed by Matthew Warchus, Stratford upon Avon, 2002), as the Clown offered himself as a pawn to Autolycus he took a leap forward, slapping his arms along his body in the posture of a soldier-pawn standing at attention.

\section{Final remarks}

I hope to have been able to show that, despite editorial silence, the word pawn still deserves some attention as one more example of Shakespeare's skill at playing with words on the margins of polysemy and homonymy. I also hope I have been able to demonstrate that drawing on the language of his contemporaries as well as on his own can help us cast some light on those dark corners of Shakespeare's meaning that still remain unexplored. Needless to say, whether any of these instances of pawn are definite allusions to chess is difficult to say; equally difficult is to determine whether Shakespeare was aiming to produce such readings when he wrote, or if he was conscious of his "choice" of words. In this respect I agree with Crane (2001:29) that we need not imagine that Shakespeare does this consciously, but simply that he does it. And when we suspect that there is the slightest possibility that he may be exploiting the full range of possible meanings available in ways like those I have shown above, then we should not hesitate to take our chances and explore what those meanings might be, for this is the shortest way to get closer to a fuller understanding of Shakespeare's meaning and style - and an effort worth making. 


\section{References}

Shakespeare's plays

\section{King John}

Shakespeare, William 1919 (1623). King John. A New Variorum Edition. Ed. Horace H. Furness. Philadelphia.

- 1936 (1623). King John. The New Shakespeare. Ed. John D. Wilson. Cambridge: Cambridge University Press.

- 1954 (1623). King John. The Arden Shakespeare ( $2^{\text {nd }}$ series). Ed. E. A. J. Honigmann. London.

— 1966 (1623). King John. The Signet Shakespeare. Ed. William H. Matchet. New York: New American Library.

— 1974 (1623). King John. New Penguin Shakespeare. Ed. R. L. Smallwood. Harmondsworth: Penguin.

- 1989 (1623). The Life and Death of King John. Ed. A.R. Braunmuller. Oxford: Oxford University Press.

- 1990 (1623). King John. Ed. Lester A. Beaurline. Cambridge: Cambridge University Press.

\section{King Lear}

Shakespeare, William 1880 (1608). King Lear. A New Variorum Edition. Ed. Horace H. Furness. Philadelphia: J.B. Lippincott \& co.

— 1901 (1608). King Lear. The Arden Shakespeare. Ed. W. J. Craig. London: Methuen.

- 1952 (1608). King Lear. The Arden Shakespeare ( $2^{\text {nd }}$ series). Ed. K. Muir. London.

— 1993 (1608). King Lear. Ed. J. F. Andrews Everyman.London: J.M. Dent Sons.

— 1993 (1608). King Lear. Eds. B. Mowatt and P. Werstine. The New Folger Library, Washington Square Books, New York.

— 1997 (1608). King Lear. The Arden Shakespeare (3rd series). Ed. R. A. Foakes. London.

— 2000 (1608). King Lear. Ed. S. Wells. Oxford: Oxford University Press.

\section{The Winter's Tale}

Shakespeare, William 1898 (1623). The Winter's Tale. A New Variorum Edition. Ed. Horace H. Furness. Philadelphia: J.B. Lippincott \& co.

- 1931 (1623). The Winter's Tale. The New Shakespeare. Eds. Sir Arthur Quiller-Couch and J. Dover Wilson. Cambridge: Cambridge University Press. 


$$
\text { Gederi } 21 \text { (2011) }
$$

- 1963 (1623). The Winter's Tale. The Signet Shakespeare. Ed. Frank Kermode. New York: Signet Classics.

- 1963 (1623). The Winter's Tale. The Arden Shakespeare. Ed. J. H. P. Pafford. London: Methuen.

- 1969 (1623). The Winter's Tale. New Penguin Shakespeare. Ed. Ernest Schanzer. Harmondsworth: Penguin.

- 1996 (1623). The Winter's Tale. The Oxford Shakespeare. Ed. Stephen Orgel. Oxford: Oxford University Press.

\section{Other plays by Shakespeare}

Shakespeare, William 1998 (1598). Henry IV, Part I. Ed. David Bevington. Oxford: Oxford University Press.

- 1968 (1600). Henry V. Ed. Arthur R. Humphreys. Harmondsworth: Penguin.

- 1999 (1594). Henry VI. Part 2. The Arden Shakespeare. Ed. Ronald Knowles. London: Arden Shakespeare.

- 1982 (1623). The Taming of the Shrew. Ed. H. J. Oliver. Oxford: Oxford University Press.

- 1974. The Riverside Shakespeare. Ed. G. Blakemore Evans. Boston: Houghton Mifflin.

- 1980. The Works of William Shakespeare. Ed. David Bevington. Glenview: Scott, Foresman and Company.

\section{Other works cited}

Astrana Marín, Luis ed. and trans. 1928. El rey Lear. William Shakespeare: Obras Completas. Madrid: Aguilar.

Bacon, Francis 1857 (1604). "An Apologie in Certaine Imputations Concerning the Late Earle of Essex." Ed. James Spedding et al. The Works of Francis Bacon. Vol X. London: Longman and Co. 139-162.

Blake, Norman F. 1999. "The Study of Shakespeare's Language: Its Implications for Editors, Critics and Translators." SEDERI 10: 11-29.

Bulman, James C. 1985. "Shakespeare Georgic Histories." Shakespeare Survey 38: $37-48$.

Coquillette, Daniel R. 1992. Francis Bacon. Stanford: Stanford University Press.

Conejero, Manuel Á. et al. ed. and trans. 1995. El rey Lear, de William Shakespeare. Instituto Shakespeare de Valencia. Madrid: Cátedra.

Crane, M. T. 2001. Shakespeare's Brain: Reading with Cognitive Theory. Princeton and Oxford: Princeton University Press. 
Crystal, David 2004. Shakespeare's Words: A Glossary and Language Companion. Harmondsworth: Penguin.

Empson, William 1930. Seven Types of Ambiguity. London: Chatto and Windus.

- 1951. The Structure of Complex Words. London: Chatto and Windus.

Foster, John 1908. A Shakespeare Word-Book: being a glossary of archaic forms and varied usages of words employed by Shakespeare. London: George Routledge \& Sons.

Freeman, Donald C. 2002. "Afterword." Eds. E. Semino and J. Culpeper. Cognitive Stylistics: Language and Cognition in Text Analysis. Amsterdam: John Benjamins. 319-324.

Freeman, Donald C. 2004 (1995). "'Catch[ing] the nearest way': Macbeth and cognitive metaphor." Eds. J. Culpeper, M. Short and P. Verdonk. Exploring the Language of Drama: From Text to Context. London and New York: Routledge, The Interface Series. 96-111.

Jonson, Ben 2000 (1632). The Magnetic Lady. The Revels Plays. Ed. Peter Happé. Manchester: Manchester University Press.

Lewis, Clive. S. 1960. Studies in Words. Cambridge: Cambridge University Press.

Loughrey, Bryan and Taylor, Neil 1982. "Ferdinand and Miranda at Chess." Shakespeare Survey 35: 113-118.

Lyly, John 1902 (1589). "Pappe with a Hatchet." Ed. Richard W. The Complete Works of John Lyly. Vol. III. 3 vols. Oxford: Clarendon Press.

— 1902 (1578). “Euphues. The Anatomy of Wit." Ed. Richard W. Bond. The Complete Works of John Lyly. Vol. I. 3 vols. Oxford: Clarendon Press.

Mahood, Molly M. 1957. Shakespeare's Wordplay. London and New York: Methuen.

Middleton, Thomas 1966 (1624). A Game at Chess. New Mermaids. Ed. J. W. Harper. London: Ernest Benn.

- 1993 (1624). A Game at Chess. The Revels Plays. Ed. T. H. Howard-Hill. Manchester: Manchester University Press.

Muir, K. 1950. "The Uncomic Pun." Cambridge Journal 3: 472-485.

The Oxford English Dictionary ( ${ }^{\text {nd }}$ ed.) 1989. Oxford: Oxford University Press.

Onions, Charles Talbut 1911 (1986). Shakespeare Glossary. Oxford: Clarendon.

Parker, P. 1996. Shakespeare from the Margins: Language, Culture, Context. Chicago: Chicago University Press.

Poole, William 2004. "False Play: Shakespeare and Chess." Shakespeare Quarterly 55/1: 50-70. 
(8) ederi 21 (2011)

Pujante, Angel L. ed. and trans. 1983. Una partida de ajedrez. Thomas Middleton. Murcia: Universidad de Murcia.

- 1985. "La insinuación y el equívoco en A Game at Chess, de Thomas Middleton." Cuadernos de Filología Inglesa 1:7-16.

- ed. and trans. 1992. El rey Lear, de William Shakespeare. Madrid: EspasaCalpe.

Schmidt, Alexander 1971 (1902). Shakespeare Lexicon and Quotation Dictionary (revised by G. Sarrazin). 2 vols. New York: Dover Publications.

Tilley, Morris P. 1926. "A Parody of Euphues in Romeo and Juliet." Modern Language Notes 41/ 1: 1-8.

Traugott, Elizabeth C., and Dasher, Richard B. 2002. Regularity in Semantic Change. Cambridge: Cambridge University Press.

Valverde, José $\mathrm{M}^{\mathrm{a}}$ 1967. King Lear. Shakespeare. Obras Completas. Barcelona: Planeta.

Yachnin, Paul 1982. "A Game at Chess and Chess Allegory." Studies in English Literature, 1500-1900 22/2: 317-330.

How to cite this article:

Oncins Martínez, José Luis. "Shakespeare and Chess Again: A Proposal for an Alternative Reading of pawn(s) in King Lear, King John and The Winter's Tale." SEDERI 21 (2011): 29-47.

Author's contact: oncins@unex.es

Submission: 21/11/2010

Acceptance: 24/1/2011 